The Dhaka University Journal of Linguistics: Vol. 2 No.4 August 2009 Page: 115-137, Published on August 2010 by the Registrar, Dhaka University ISSN-2075-3098

\section{Causative Constructions in Kok-Borok}

\author{
Md. Kamrul Hasan ${ }^{1}$
}

1. Assistant Professor in English, English Language Institute United International University mkhasan77@gmail.com

\begin{abstract}
Kok-Borok is the native language of the Borok people in the Indian state of Tripura and its neighbouring areas of Bangladesh. The aim of the present study is to capture the typological analysis of causative constructions of Kok-Borok, a language which belongs to the Bodo sub-group of the TibetoBurman language family. Our study shows that the most remarkable aspect of the causative constructions in Kok-borok is that in double causatives, the causative rI 'give' has been reduplicated in order to express 'to make somebody to do by employing a third party', which shows the language KokBorok's unique features if we compare this language with the other South-Asian Tibeto-Burman languages. The findings of mixed causatives show that both periphrastic and morphological devices have been employed in Kok-Borok to convey the meaning of causative constructions.
\end{abstract}

Key Words: Causatives, Lexical, Morphological or Periphrastic Causatives, Kok-Borok.

Kok-Borok is the native language that is spoken by the Borok people belonging to the state of Tripura, India and is also spoken in some parts of Bangladesh. The term 'Kok-Borok' is actually a compound of the main words and these are 'kok' that literally means 'language' and 'borok' that means 'nation'. But interestingly, the second word is used to denote the Borok people (Bulbul 2000) who belong to
Tripura; thus, in simple terms, it can be said that Kok-Borok literally means 'the native language of the Borok people'. According to Pai (1976), Kok-Borok shows all the characteristic features of the Bodo sub-group. It has altogether thirty phonemes, including tones out of which twenty-one are consonants, seven vowels and two tones. KokBorok was recognized as an official language of Tripura state in 1979. There currently is a debate over giving the language recognition as a National language of India. Kok-Borok had a script known as Koloma which has disappeared now. Since the $19^{\text {th }}$ century the Kingdom of Tripura used the Bengali script for writing KokBorok. Since the independence of India and Tripura's merger with India the Roman script is being promoted by non-governmental organizations. The script issue is highly politicized as the Left Front government is advocating usage of Bengali script and the Tripuri Christians and ethono-nationalists are advocating for the Roman script (Kunduchoudhury 2006). At present both the scripts are being used in the state, in education as well as in literary and cultural circles. Several Borok scholars, of course, have been thinking about the script, and a good system is used in the remarkable dictionaries edited by Debbarma (2002).

According to Bulubul (2000), many tripuris live in some parts of Bangladesh, such as, Khagrachari, Chadpur, Rangamati, Bandorban, Rajbari, Mymensingh, Dhaka, Faridpur, Chittagong, Comilla, Noakhali, and Sylhet, but the majority of them lives in Chittagong Hill Tracts. Bulbul mentions that Kok-Borok is divided into 36 dialects. Out of them, 16 dialects can be traced in Bangladesh. He also has mentioned that Tripura or Kok-Borok can be classified into 27 sound groups. Grierson (1927) in his Linguistics Survey of India has termed tripura language rich. With the passage of time, Kokborok has come in contact with Bangla, Arabic, Persian, English languages, and has accorded many words as their own resulted in assimilation; as a result, the characteristics and pronunciation of the original language have not maintained in Kok-Borok rather they maintain own style of pronunciation of Kok-borok. He also (Bulubul 2000:48) says, "not only this, as of necessity, in future those words which will be incorporated in Kok-Borok will follow the own rules of Kok-Borok". 
The Tripuris is the third largest population among other tribes in Chittagong Hill Tracts. According to Bulbul (2000), their number can be nearly one lakh (1991 cencus-81,014).

The total number of Tripura in India and Bangladesh is near about ten lakhs. According to Jacquesson (2003), the Tibeto-Burmese group of about 250 languages, spoken in eastern Asia, is related to the Chinese languages with which it forms the Sino-Tibetan supergroup. Tobeto-Burmese languages can be divided into several subgroups, among which we find the Bodo-Garo sub group. Dimasa Boro and Kok-Borok form a first branch Garo; Rabha Tiwa form a second branch; Deuri forms a third branch by itself. According to Thakurta (1999), the language is spoken by 2,68,948 (1971 census) people and has thirteen dialects among Debbarma, Riang, Halam, and Tipra (as known as Noatia) are the numerically large groups. Debbarma dialect is spoken by the members of the royal family and has been the medium of communication with the rest of Tripuri public for a long time. Debbarma dialect is understood by all the dialect groups but its vice versa is not true. Hence, Debbarma dialect is considered as the standard form of Kokborok. Grierson in his Linguistic Survey of India classified Kok Borok as Tipura under Bodo group of Tibeto-Burman language family. Kunduchoudhury (2006) mentions that the Garo language should not be considered as sister-dialect of Kok-Borok and it needs further research. In course of time, the term Tripuri has become synonymous with Kok-Borok. Kok-Borok is a Tibeto-Burman language family of East-Asia and South East Asia. It is closely related to the Bodo language and the Dimasa language of neighbouring state of Assam, India.

The present work involves in the study of causative constructions in Kok Borok, a language which belongs to the Bodo sub-group of the Tibeto-Burman language family. The main objective of the study is to capture the analysis, regarding the causative constructions in Kok Borok.

\section{Theoretical Background}

According to Comrie (1975), syntactically, if we assume a hierarchy of grammatical relations "subject, direct object, indirect object,

The Dhaka University Journal of Linguistics other", the grammatical relation assumed by the cause (i.e the subject of the corresponding non-causative) seems to occupy the highest position on the hierarchy that is not otherwise occupied. Comrie (1976) expresses the view that generally a causative verb will have one more noun phrase argument in compassion with its corresponding non-causative verb. $\mathrm{He}$ also assumes that the underlying structure of a causative sentence combines a matrix and an embedded sentence. The matrix sentence will have a subject noun phrase (corresponding to the causer of the action) while the embedded sentence has a subject noun phrase (the person who in fact carries out the action), possibly along with one or more object noun phrase.

For Shibatani (1976), to define the causative constructions is not an easy matter. Shibatani also mentioned that like English, two types of causative forms are seen in a large number of languages. One of them is morphologically regular and productive forms, and the other one is morphologically irregular, nonproductive forms. The latter is referred to as lexical causatives and the former is referred to as productive causatives.

The term "causative construction" refers to any grammatical device that encodes causation. The role played by causative constructions is important in the recent history of linguistics not only from typological viewpoint but also from its manifestations of an important convergence between linguistics and other disciplines, such as, philosophy and cognitive anthropology. Causative constructions play significant role among semantics, syntax and morphology, even within a single language or preferably crosslinguistically.

Causative constructions can be classified into two major types based on the productivity or regularity of causative forms, namely, productive causatives and lexical causatives. Productive causatives may be further classified into subtypes: syntactic and morphological causatives. Syntactic causatives are alternatively called as analytic causatives or periphrastic causatives. Morphological causatives are alternatively called as synthetic causatives; thus, we can say that causatives can broadly be classified into three types:

Vol. 2 No. 4, August 2009 
1) Lexical Causatives

2) Morphological Causatives

3) Periphrastic Causatives

Lexical Causatives: lexical causatives refer to morphologically irregular, nonproductive causative forms. They are typically manifested in languages as a class of transitive verbs refer to as causative transitive verbs, such as cut, destroy, open, melt, boil, etc. in English. Causative transitive verbs designate the type of event that meets most of the criteria for our cognitive category of prototypical causation in the sense of Lakoff (1987: 54-55). In prototypical causation, an agentive participant volitionally and directly transfers physical energy onto the second participant. The second participant then undergoes a change of state as a result of the agent's action. On this basis, it could be claimed that a lexical causative which is manifested in the form of a transitive verb, expresses two major sub events: the agent's activity and the patient's change of state. Some transitive verbs have fairly clear non-causative counterparts. These may be considered as lexical causatives. For example, the transitive verb kill is the causative of die in English. It has been claimed that many linguistics whose work touches on the notion of causatives that lexical causatives tend to signal direct, manipulative causation whereas syntactic causatives tend to express indirect causation (Shibatani 1973, Jackendoff 1990, Matsumoto 1996). Certain noncausative verbs in some languages may not have 'corresponding lexical causatives' which refer to transitive causative verbs that are identical or phonologically related to non-causative verbs.

In lexical causatives, a language simply uses a different lexical item to indicate a causative form.

\section{Example from Kok-Borok:}

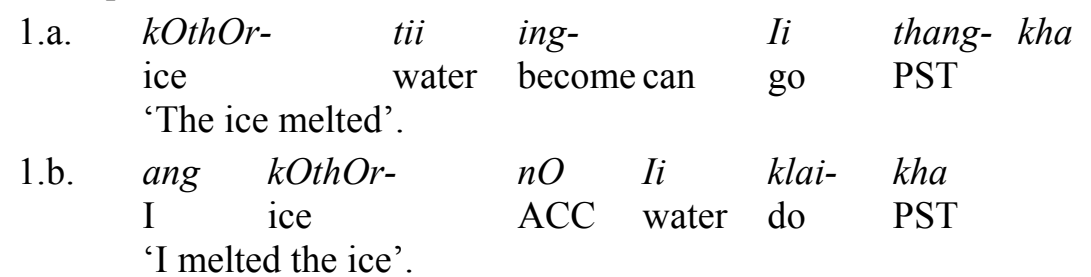

$\begin{array}{llll}\text { 2.a } & b O \text { thui } & k h a & \\ & \text { he die } & \text { PST } & \\ \text { 'He died'. } & & \\ \text { 2.b. } & \text { ang bO- } & \text { nO } & \text { buthar- } k \text { ha } \\ & \text { I hill }\end{array}$

In the above sentence (2b), the subject of an intransitive caused event is treated as the object of the causative constructions. In any causative situations, causatives are expressed by a completely different lexical item, referred to as lexical causatives. In terms of lexicality, the relationship between the expression of effect and the expression of causative micro-situation is widely unsystematic. They are arbitrary and language-specific (Shibatani 1973). Two different predicates or lexical items, though they are semantically and lexically related, express the "causee" and the "effect" without any morphological resemblance.

Examples of lexical causative and non-causative counterpart are given in the Table 1 below.

Table 1: Examples of lexical causative

\begin{tabular}{|l|l|l|l|l|}
\hline & \multicolumn{1}{|c|}{ N.C } & \multicolumn{1}{c|}{ Gloss } & \multicolumn{1}{c|}{ C } & Gloss \\
\hline Eng & learn & & teach & \\
\hline & fall & & drop & \\
\hline & rise & & raise & \\
& lie & & lay & \\
\hline & sit & & set & \\
\hline & thI & "die" & buthar & "kill" \\
\hline & thá & "to go" & ror & "to send" \\
\hline & $n u k$ & "to see" & funuk & "to show" \\
\hline
\end{tabular}

Here, Eng stands for English, and KB stands for Kok-Borok. N.C means Non-causative, and $\mathrm{C}$ means Causative.

Morphological Causatives: Causations expressed by means of a productive suffix are referred to as morphological causatives. 
Mainly, we find the following two characteristics regarding this. First, the causative is related to the non-causative predicate by morphological means; it may be by the help of affixation or other morphological techniques the language concerned can employ for the purpose. The second characteristic involves the means of relating causative and non-causative predicates productivity aspect.

In an ideal type, we assume that any predicate can form a causative form by the appropriate morphological means. We see a lot of examples of this type of causatives in Kok-Borok. The language Turkish comes very close to this ideal. The central point is, here, "the cause" and the non-causative verb are fused into one to form a causative construction.

Table 2: Examples of morphological causatives

\begin{tabular}{|c|c|c|c|c|}
\hline & N.C & Gloss & Causative & Gloss \\
\hline Hindi & banana & $\begin{array}{l}\text { "to } \\
\text { construct" }\end{array}$ & banvana & $\begin{array}{l}\text { "to make } \\
\text { construct" }\end{array}$ \\
\hline \multirow[t]{8}{*}{ K.B } & chá & "to eat" & chá-rI & "to make eat" \\
\hline & báy & "be broken" & sI- báy & "break" \\
\hline & rung & "'know" & su-rung & "learn" \\
\hline & kIrang & '“dry' & phIrang & "make dry" \\
\hline & $r \operatorname{Ing}$ & "know" & phIrIng & "make know" \\
\hline & $l O k$ & "long" & phO-lOk & "lengthen" \\
\hline & thak & "wait" & bO-thak & $\begin{array}{l}\text { "stop } \\
\text { someone" }\end{array}$ \\
\hline & sIi & "write" & $s I i-r I$ & $\begin{array}{l}\text { "to make } \\
\text { write" }\end{array}$ \\
\hline
\end{tabular}

Here, K.B stands for Kok-Borok, N.C means Non-causative, and C means Causative

In some languages, we see another morpheme can be afiixed to the already morphologically causitivized verb in order to form double causatives.

The Dhaka University Journal of Linguistics
Table 3: The presence of the double causatives

\begin{tabular}{|l|l|l|l|l|l|l|}
\hline $\begin{array}{l}\text { Hind } \\
\mathrm{i}\end{array}$ & N.C & Gloss & C & Gloss & D.C & Gloss \\
\hline & rona & "to cry" & rulaanaa & $\begin{array}{l}\text { "to make } \\
\text { cry"” }\end{array}$ & rulvaanaa & $\begin{array}{l}\text { "to make cry by } \\
\text { somebody" }\end{array}$ \\
\hline K.B & $k \dot{a}$ & "to cry" & $k a ́-r I$ & $\begin{array}{l}\text { "to make } \\
\text { read" } \\
\text { read" }\end{array}$ & paRaanal-rI-rI & $\begin{array}{l}\text { "to make cry by } \\
\text { somebody" }\end{array}$ \\
\hline & sang & $\begin{array}{l}\text { "to } \\
\text { fetch" }\end{array}$ & sang-rI & $\begin{array}{l}\text { "to make } \\
\text { fetch" }\end{array}$ & sang-rI-rI & $\begin{array}{l}\text { "to make fetch } \\
\text { by somebody" }\end{array}$ \\
\hline & thui & "to die" & thui-rI & $\begin{array}{l}\text { "to make } \\
\text { die" }\end{array}$ & thui-rI-rI & $\begin{array}{l}\text { "to make die by } \\
\text { somebody" }\end{array}$ \\
\hline
\end{tabular}

Syntactic Causatives: Syntactic Causatives are also known as analytical or periphrastic causatives. Syntactic causatives involve separate predicates which express the notion of causation and the predicate of the effect. For example, I caused John to go.

Here, in the above sentence, we identify "cause" as cause and "go" as effect; both of them are separate predicates. In spite of many of these causatives figure in various languages, where we see they come close to ideal types of syntactic causatives, we also find many causative constructions which fall into a category as intermediary between analytic and morphological causatives. Though the formally analytic French construction faire is "to make", it consists of many syntactic properties of a morphological causative. The recursive pattern is shown below
French
(laisser) $+[\mathrm{verb}]$
(faire) + [verb]

In the cross-linguistic comparison of causative constructions, the grammatical encoding of the semantic relation causee in the causative constructions becomes crucial in addition to the classification of the analytic, morphological and lexical causatives.

In some languages, we see the other strategic employment for expressing causative constructions, and this process is not purely periphrastic. It is observed that periphrastic causatives have used morphological devices, that is, both morphological and periphrastic

Vol. 2 No. 4, August 2009 
devices have been employed in expressing causative constructions, such as in Hindi.

us- ne raaam- se kha- vaa- kaar kaam kar- vaa$y a$ he ERG Ram ACC tell CAUS cpm work do CAUS PST

"He got the work done by having someone asked Ram to do it".

Davidson (1967) suggests that the traditional arguments of the verb, particularly the subject and object of an action sentence should be expressed in separate conjuncts. This is termed as Neodavidsonian analysis, which makes quite radical change to Davidson's original proposal. Neodavidson representation decomposes the verb into a simple predicate on the event. John killed Stimson

An alternative representation for "John killed Stimsosn" breaks the verb kill down into smaller components more closely corresponding to sub-events parts of the whole event - in such a way that relations of arguments to the killing event are expanded.

(a) [DO(j) CAUSE [BECOME [NOT ALIVE (s) ]]]

(b) A Doing by John causes it to BECOME the case that Stimson is NOT ALIVE.

The verb kill is broken down into the components DO, CAUSE, BECOME, NOT, and ALIVE. The component predicates, such as, DO and CAUSE are elements of sublexical analysis, and are not the same as the meanings of the corresponding English words, such as do, cause and so on. The verb cause can be used for any type of causation, including direct or manipulative causation and indirect or influential causation, but the predicate CAUSE expresses direct causation only. This method is widely used by syntaxticians semanticists in 1960 onwards. To die is basically a composite predicate; that is decomposed into become not alive.

Die

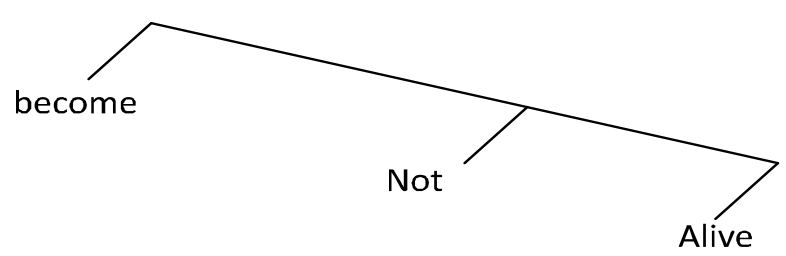

"Kill" therefore is

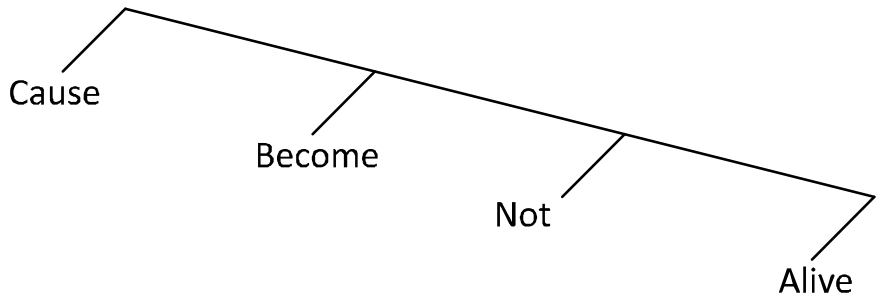

Figure 1a

Semanticians around the year 1960 propose that X kill Y can be derived from the following underlying structure by Successive Predicate Raising.

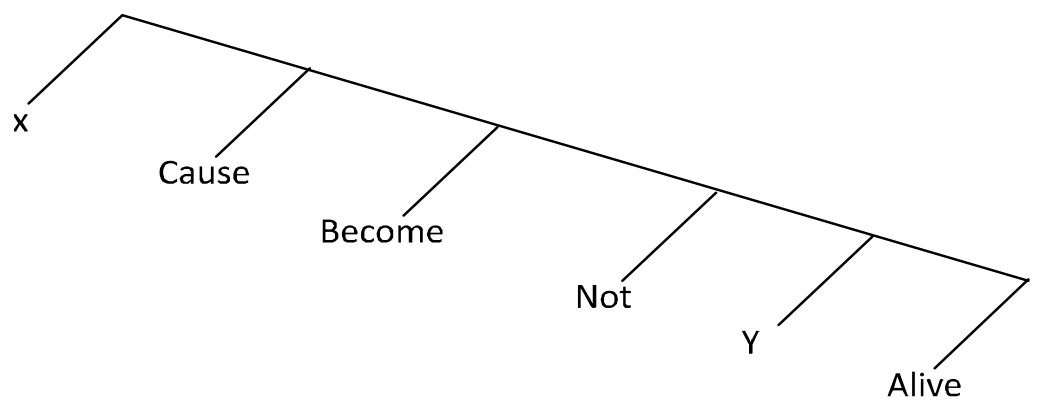

Figure 1b

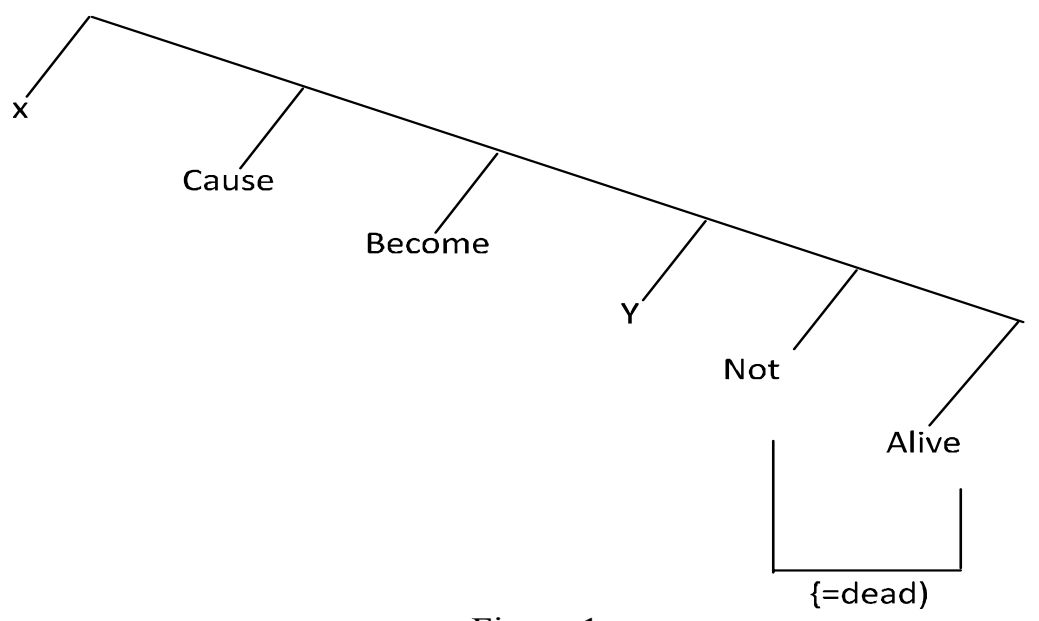

Figure 1c 


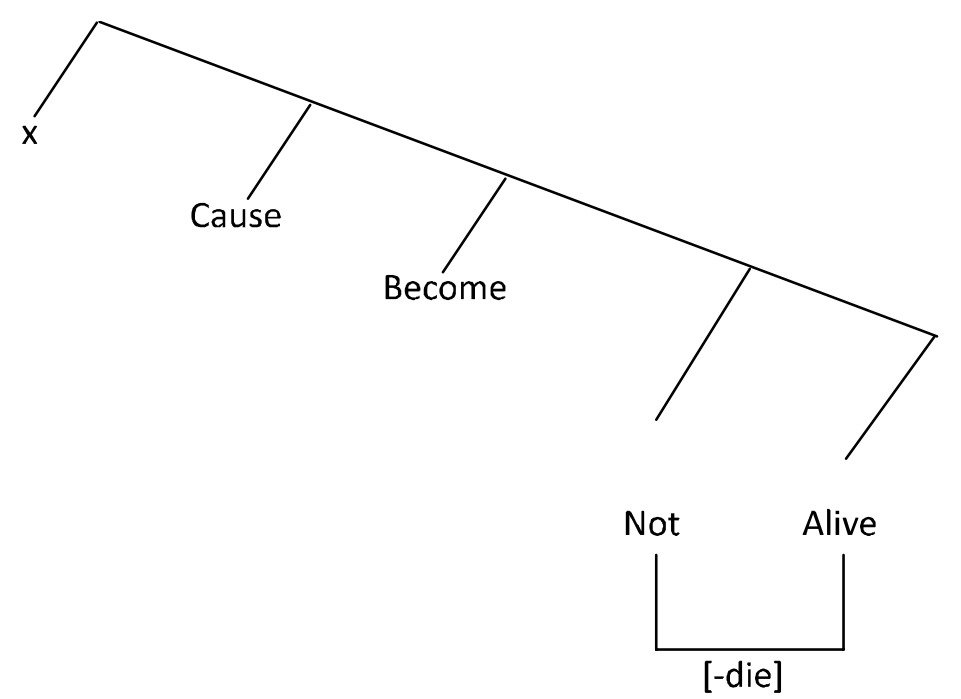

Figure 1d

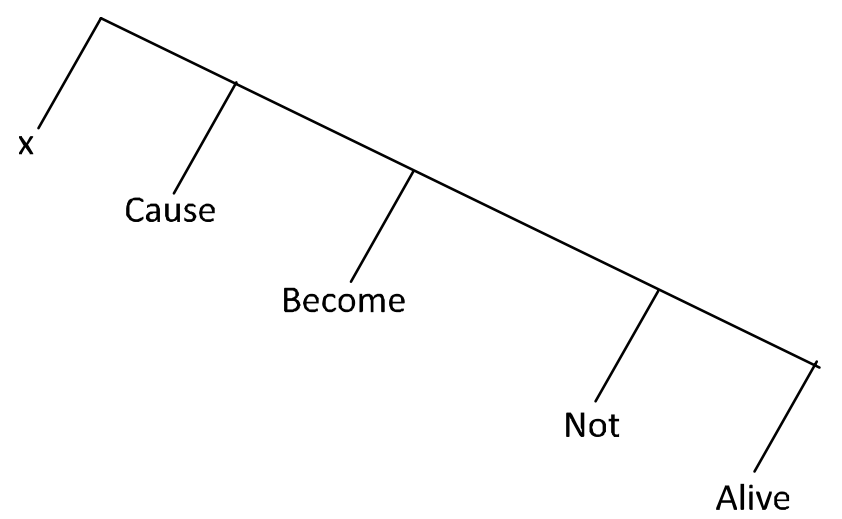

Figure 1e

We can also mention a role (thematic), such as theme in terms of Agentive causative:
$[\operatorname{Do}(\mathrm{x})$ Jones broke the pot
Cause $[\ldots \ldots \ldots \ldots \ldots \ldots . . . \ldots$
[Do (j, the pot) Cause [Become [Broken (the pot)]]
b. John dragged Fido outside [Do DRAG (j. f)] [CAUSE [GO (f. [AT (f. outside)]].

Grammatical expressions of the causee in certain cases are allowed in some languages. Cole (1983) says that they are often correlated with semantic distinctions.

Baker (1988) says that in morphological causatives, a single verb does not correspond to a verb and a noun rather they do to two verbs. He claims that at the level of abstraction, morphological causatives are like Noun Incorporation, except for the category of the word being moved. In his analysis, he shows that a lexical item undergoes syntactic movement to combine other lexical item in the structure in order to account for the surface structure, where the verb root must leave a trace to allow theta role assignment to the "stranded" subject and to head the embedded the embedded causal complement which the causative morpheme lexically selects. The Uniformity of Theta Assignment Hypothesis maintains that there remains a parallel structure between D-structure and S-structure. He also mentions that morphological causatives are Verb Incorporation. They are derived by movement which shows its strong similarities with Chomsky's (1981) "subject-to-subject" rising, which is also derived by movement.

Ackerman and Webelhuth (1998) in their analysis of causatives have raised issues concerning the determination of grammatical functions, clause boundaries, and the borderline between syntax and morphology, among others. They try to show that like other predicates, causatives traverse the syntax-morphology boundary. Their aspects can be expressed synthetically in one construction and analytically on another. They mention that causatives semantically express two states of affairs. The bipropositional structure motivates some causatives behave as biclausal structures in certain respects, e.g., the binding of anaphoric pronouns; however, this is not always so, in many languages causative predicate consistently behave as if 
they project one single clause. There is also a third class of causatives, which is referred to as "mixed' causatives, such as, constructions evince monoclausal and biclausal properties.

The causative types they categorize according to clausality and synthetically are in the following table:

Table 4

\begin{tabular}{|l|l|l|}
\hline & Analytic & Syntactic \\
\hline Monoclausal & German I & Malayalam \\
\hline Biclausal & German II & Ch-Mwi:ni \\
\hline Mixed & Italian & Turkish \\
\hline
\end{tabular}

\section{Causative Constructions in Kok-Borok}

Kok-Borok belongs to the type of an inflecting language as there is seldom one-to-one matching of morphemes with morphs; instead, a single morph is likely to represent several morphemes simultaneously. The presence of lexical causatives in this language is insignificant in terms of morphological causatives as this language is very rich in phonology, morphology. We can take up the following examples:

$\begin{array}{llllll}\text { 1.a. } & a \eta \quad b i-n i & n O g- & O & \text { thay- } & k h a \\ \text { I he of house } & \text { LOC } & \text { go } & \text { PST } \\ \text { "I went to his house". } & & & \\ \text { 1.b. ay bO- } n O & \text { ror- } & k h a & \\ & \text { I he } & \text { ACC } & \text { send } & \text { PST } & \\ \text { "I sent him". } & & & \end{array}$

From these examples, we see that the word for 'go' in Kokborok is thang and for 'send' in Kokborok is ror, and a different lexical item is used to indicate a causative form; thus, they form the type of causatives which can be referred to as lexical causatives.

$\begin{array}{llllllll}\text { akung wakhirai- } & \text { nO mithIi- } & \text { kha humba } & \text { bO thli li- } & y a \\ \text { Akung } & \text { Wakhirai } & \text { ACC cause to die } & \text { PST } & \text { but he die- } & \text { EMP NEG } \\ \text { ache } & b O & \text { wakhirai- } & n O & \text { buthar- } & k h a & \\ \text { then he } & \text { Wakhirai } & \text { ACC } & \text { kill } & \text { PST }\end{array}$

"Akhung caused Wakhirai to die, but he did not die, then he killed Wakhirai".

The Dhaka University Journal of Linguistics
Unlike English, the obvious lexical causative of 'eat' and 'feed' is not seen in Kok-Borok rather the same causative is manifested under morphological causatives.

\begin{tabular}{|c|c|c|c|c|c|}
\hline 1. a. & $\begin{array}{l}n I y \quad \text { chá- } \\
\text { you eat } \\
\text { "Are you eating }\end{array}$ & $\begin{array}{l}I i \\
\text { PROG } \\
\text { ??" }\end{array}$ & $\begin{array}{l}\text { de } \\
\mathrm{y} / \mathrm{n} \mathrm{q} \mathrm{mrk}\end{array}$ & $\begin{array}{l}t O \eta \\
\text { be }\end{array}$ & \\
\hline 2. b. & $\begin{array}{ll}b O & \text { ano } \\
\text { he } & \text { I-ACC }\end{array}$ & $\begin{array}{l}\text { lepsa } \\
\text { biscuit }\end{array}$ & $\begin{array}{l}\text { chá- } \\
\text { eat }\end{array}$ & $\begin{array}{l}r I \\
\text { CAUS }\end{array}$ & $\begin{array}{l}k h a \\
\text { PST }\end{array}$ \\
\hline
\end{tabular}

From the above sentence (2.b), we can see that the subject of transitive caused event is treated as the indirect object of the causative construction. We can classify the verbs in Kok-Borok into intransitive, transitive and causatives. We see morphological causatives are formed into two ways, that is, from the intransitive verbs as well as from transitive verbs. We will refer non-causative intransitive verbs as (N.C) and its counterpart causatives as (Caus).

For examples: Table 5

\begin{tabular}{|l|l|l|l|}
\hline N.C & Gloss & Caus & Gloss \\
\hline kutuy & 'be hot' & mutuy & 'make hot' \\
\hline thak & 'stop' & mithak & 'stop someone' \\
\hline thu & 'sleep' & mu-thu & 'put to sleep' \\
\hline sup & 'blow' & mu-sup & 'whistle' \\
\hline tháy & 'be alive' & ma-thán & 'put life into' \\
\hline
\end{tabular}

From the above table, we see that morphological causatives are formed by adding four transitive prefixes to the intransitive verbs, and these prefixes do not show any semantic distinction between themselves; therefore, the choice of a particular prefix to make transitive from intransitive seems to be lexically conditioned.

In this language, we see that adjectives can be not only used as verbs but also can be used under causatives, using $m I$ prefix, such as,
kwthwi muthwi
kIrang
dead' " to make dead'
'dry'
phIrang'

Both $b I$ - and $m i$ - are in morphophonemic variation.

Vol. 2 No. 4, August 2009 
The other type of morphological causatives in the language KokBorok is represented by adding the verb $r I$ - 'give' to the transitive verb as well as to the intransitive verbs.

Transitives (includes diatransitives)

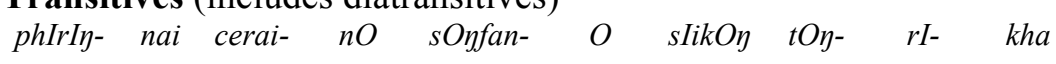
teach er boy ACC table LOC pen pen CAUS PST

"The teacher made the boy put the pen on the table".

\section{Intransitives}

\begin{tabular}{|c|c|c|c|c|}
\hline I.a. & $\begin{array}{l}\text { muibIsakOtOr } \\
\text { plant } \\
\text { "The plant grew" }\end{array}$ & $\begin{array}{l}\text { Iy- } \\
\text { big }\end{array}$ & & $\begin{array}{l}k h a \\
\text { become PST }\end{array}$ \\
\hline 1.b. & $\begin{array}{c}\text { bárinainai muiblsa- } \\
\text { gardener plant }\end{array}$ & $\begin{array}{c}n O \\
\mathrm{ACC}\end{array}$ & $\begin{array}{l}\text { kOtOr- } \\
\text { big }\end{array}$ & $\begin{array}{c}r I- \\
\text { CAUS }\end{array}$ \\
\hline
\end{tabular}

"The gardener made the plant grow".

Double causatives will have two extra NPs along with an agent or a doer. They refer to a situation where the agent or doer does not physically cause the event, but manipulate it through an intermediate agent. This can be explained by the following:

$\mathrm{X}$ made $\mathrm{Y}$ performs by $\mathrm{Z}$.

We see the existence of double causatives in Kok-Borok. The presence of double causatives shows a phenomenal perspective as the reduplication of causative marker $r I$ - 'give' has been employed to convey the meaning of double causative constructions.

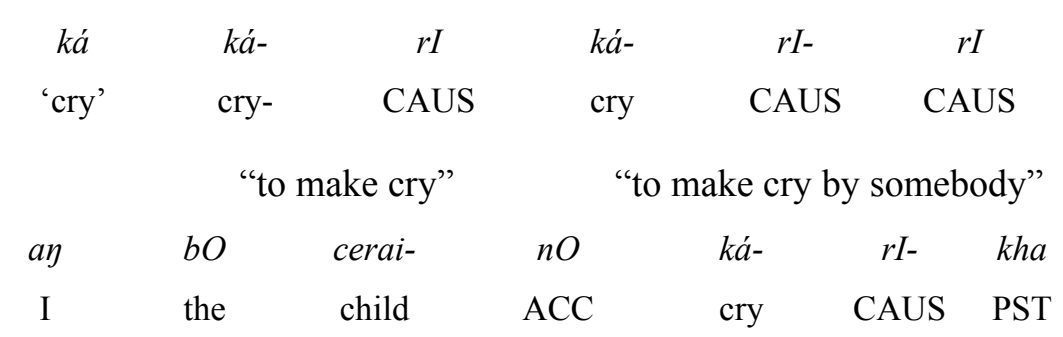

"I made the child cry"

The Dhaka University Journal of Linguistics
Here, in the above sentence, ang "I" is the agent to make the child cry; however, when the child is made to cry by someone, we will have the reduplication of the causative $r I$ 'give'.

$\begin{array}{cccccccc}a \eta & b O & \text { cerai- } & n O & k a ́- & r I- & k h a & \\ \text { I } & \text { the } & \text { child } & \text { ACC } & \text { cry } & \text { CAUS } & \text { CAUS } & \text { PST }\end{array}$

"I made the child cry (by somebody)".

In this language, when we simply ask the informants, we see the distinction between 'to make cry' and 'to make cry by somebody' is very thin, and sometimes, the distinction is lost at the level of morphology. By syntactically putting forward to informants, when 'it is mentioned by somebody' is asked and represented in Kok-Borok, the distinction between 'to make cry' and 'to make cry somebody' becomes prominent, unlike Hindi rulvaanaa 'to make cry by somebody' can be interpreted morphologically.

There is another type of causative constructions found in Kok-Bork bears significance as it falls under mixed category, which blends the employment of morphological and periphrastic devices used for causative constructions.

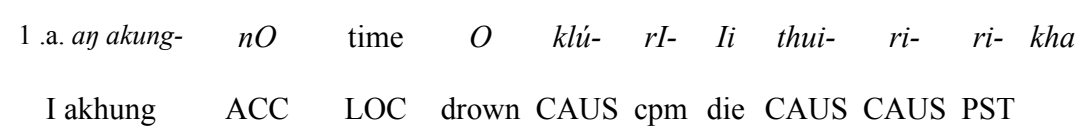

"I got Akhung killed by having someone drown Akung in the river".

1.b. burga seley- $\quad$ nO sari- $\quad$ Ii tIi say- rI- rI- kha

I akhung ACC LOC drown CAUS cpm die CAUS CAUS PST

"The master got the water fetched by having someone asked the servant to do the same."

Vol. 2 No. 4, August 2009 
From the above examples, we can not say that Kok-Borok has purely periphrastic causative constructions like English. What we can say that both morphological and periphrastic devices have been used in the language, and this type of blending process is refereed to as mixed causatives. If we take into consideration of the analysis of mixed causatives, we can say that periphrastic causatives have used morphological devices in order to make such constructions.

The causative constructions for transitive verbs can be accounted by the theory of incorporation of Baker (1998), and the theory has been taken up by Hale and Keyser (1993) in their treatment for transitive causative constructions. Now we will have a look at this from the minimalist point of view. In corporation in the sense of Baker (1998), V-incorporation to a causative verb has the structure like the following:

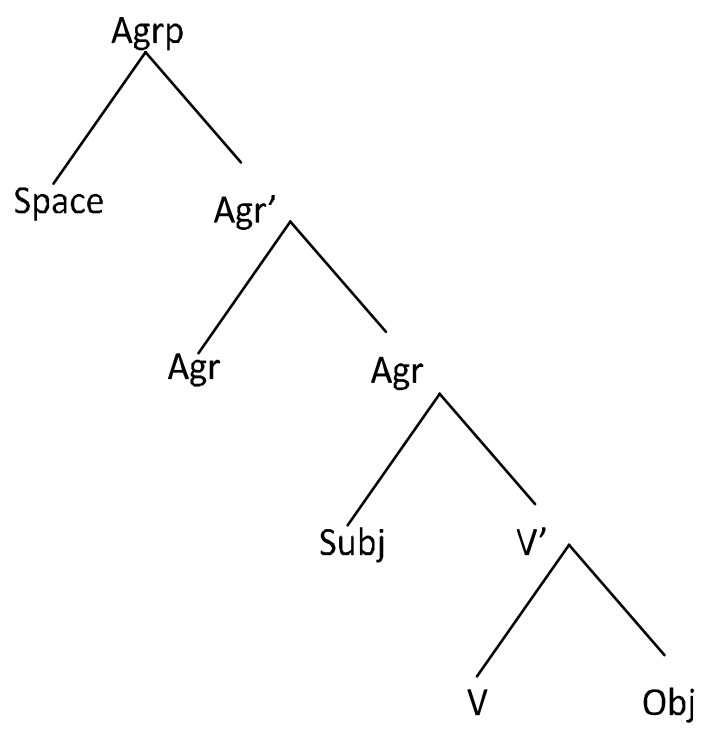

According to Baker, incorporation with an embedded clause $\mathrm{S}$ instead of the object Obj. can represented in the following way:

The Dhaka University Journal of Linguistics

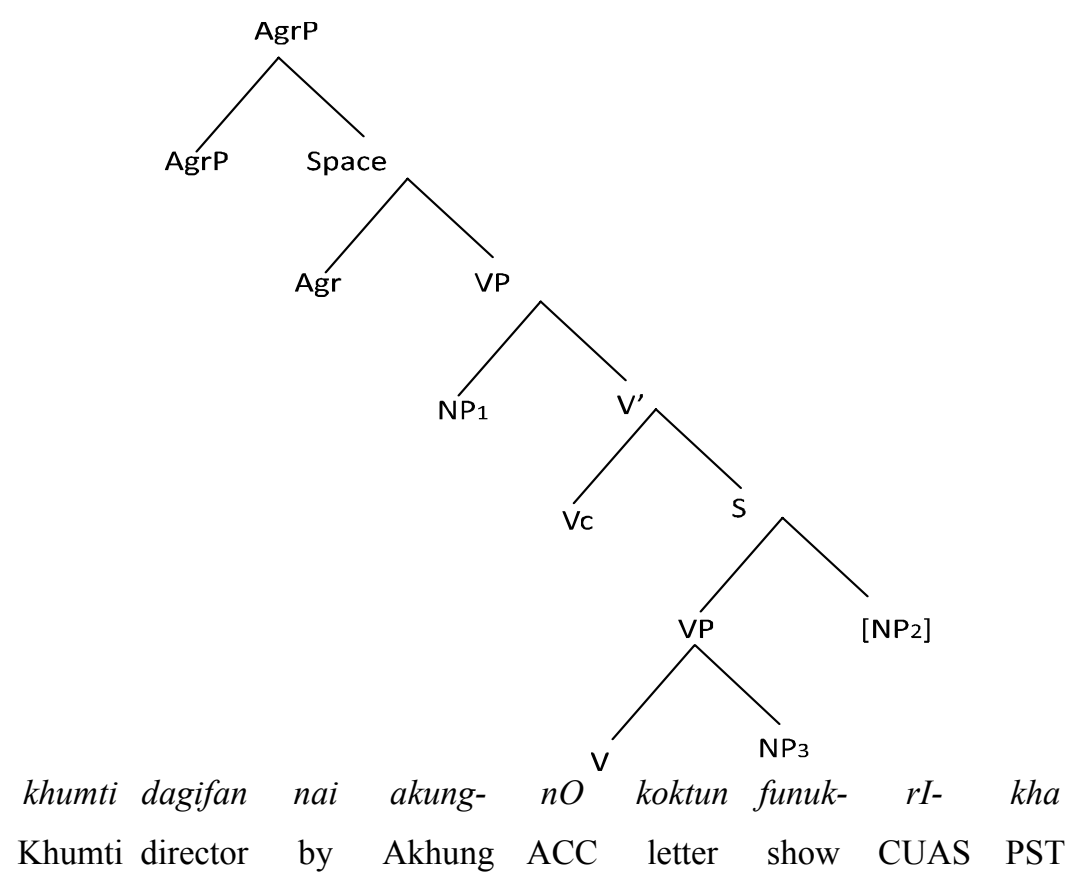

"Khumti made the director to show the letter to Akung".

For SOV language, like Kok-Borok, the structure will be-

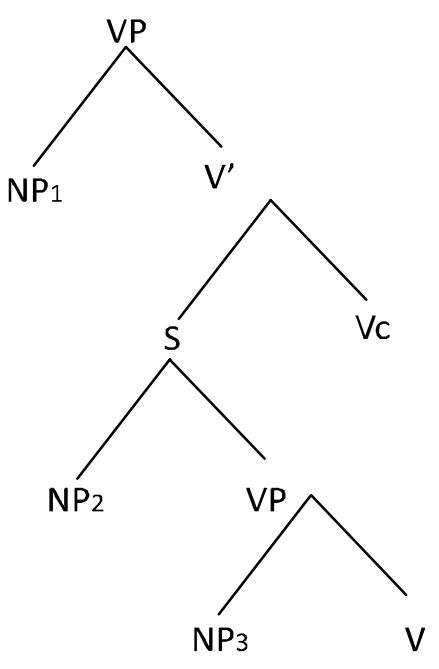

Vol. 2 No. 4, August 2009 
Here, the object will be raised to [spec, Agr] $(\mathrm{Agr}=\mathrm{Agr})$. We take $\mathrm{NP}_{1}=$ khumti, $\mathrm{NP}_{2}=$ dagifan, $\mathrm{NP}_{3}=$ koktun, $\mathrm{Vc}=r I, \mathrm{~V}=$ funuk .

Now, we see the incorporation of $\mathrm{V}$ to the causative $\mathrm{Vc}$ with $\mathrm{V}$ adjoined to $\mathrm{Vc}$. The complex head $[\mathrm{VVc}]$ is then raised to Agr. Here the $\mathrm{NP}_{3}$ is treated as the object of the verbal complex, and assigned accusative case, that means, the $\mathrm{NP}_{3}$ is raised to [spec, Agr].

The notion of 'shortest movement' (Chomsky 1996) is:

If $\mathrm{A}, \mathrm{B}$ are in the same minimal domain, they are equidistant from $\mathrm{C}$.

Taking up, this notion of the violation of 'shortest movement' condition can be accounted, assuming the conclusion that crossing and not nesting is the only permissible option in any language.

We have discussed that Kok-Borok has intransitive causatives, and transitive verbs are formed by adding four prefixes to the intransitive verbs.

$$
\text { I. a. cerai bOtOl sI- báy- kha }
$$$$
\text { child bottle CAUS break PST }
$$

"The child broke the bottle"

$\begin{array}{llrrr}\text { I. b. } & \text { bOtOl } & \text { kIbáy- } & \text { I } y- & k h a \\ & \text { bottle } & \text { break } & \text { become } & \text { PST }\end{array}$

"The bottle broke".

$S I$ is also causative marker like $r I$ - 'give'. The only difference between them is that $s I$ comes before the verb and $r I$ - comes after the main verb.

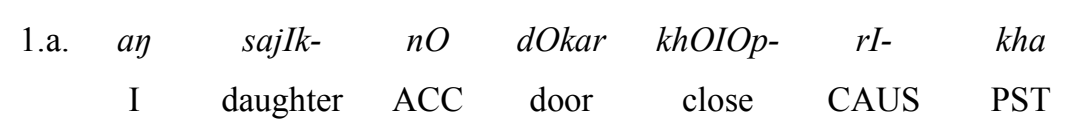

"I made my daughter to close the door".

The Dhaka University Journal of Linguistics

$\begin{array}{ccccccc}\text { 1.b. } & \text { an } & \text { cerai- } & n O & k u c u k- & r I-- & k h a \\ & \text { I } & \text { child } & \text { ACC } & \text { cough } & \text { CAUS } & \text { PST }\end{array}$

"I made the child cough".

The above example (13) has unergative form kucuk 'cough' and $r I$ is added to make it 'cause to cough'. If we try to envisage the derivation, we can see that the NP cerai 'child' is in fact in the spec position of the verb kucuk 'cough' according to the model proposed by Hale and Keyser. In their framework, it is mentioned that 'the agent' of an unergative is not strictly speaking an argument of the verb. It is an external argument, which is related to the unergative verb indirectly through prediction. The same can be true of the 'agent' of the transitive verbs as well.

The 'child' comes in the spec position of the verb; it must have permitted there by virtue of some property of the affixal causative verbs, such as, $r I$ - give. The derived verb does not indeed have the property of transitivity; therefore, requires an argument to which it can assign accusative case. We can show this by the following structure without full details-

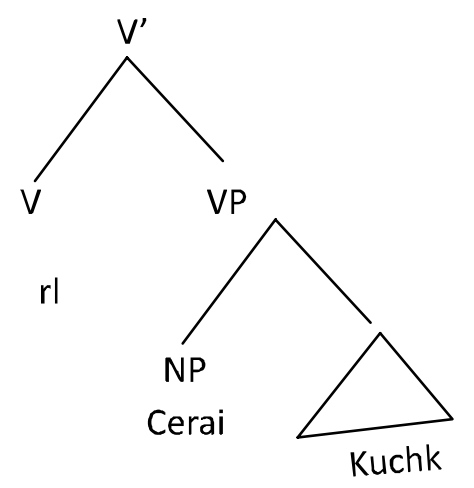

cerai 'child' appears in this position only it is forced to appear there. The predication requirement forces the appearance of a subject for verbs, whose complements are inherently predicational, that is, a 
"VP-internal motivation"; otherwise, the motivation is 'external' in the sense that the appearance of a subject is forced by properties of matrix, for example, the transitive features of a causative verb. The appearance of a subject in [spec, VP] is not a uniform phenomenon. Though internally and externally forced subjects are structurally distinct, they differ in interpretation. The former is the subject of a VP-internal predicate; in contrast, the latter is regularly interpreted as 'agents'. English unergative verbs lack causative form. The overt morphology of Kok-Borok and many hundreds of other languages have properties which force the appearance of a subject in its immediate complement of VP. The basic difference lies in the English non-overt 'causatives' is that they are devoid of properties, which could force the appearance of an NP in the spec position of its complement.

\section{Conclusion}

The most remarkable aspect of the causative constructions in KokBorok is that in double causatives, the causative $r I$ 'give' has been reduplicated in order to express 'to make somebody to do by employing third party', which shows the language Kok-Borok's unique features if we compare this language with the other SouthAsian Tibeto-Burman languages. Apart from this, another remarkable part of the study of causative constructions regarding lexical causatives shows that the presence of lexical causative is not abundant. The discussion of mixed causatives in Kok-Borok proves the point that any theory of a language can not include the entire natural and independent role played by languages of the world. The study shows that the limitations of our linguistic theory, which we try to impose on language. The findings of mixed causatives show that both periphrastic and morphological devices have been employed in Kok-Borok to convey the meaning of causative constructions.

\author{
Abbreviations \\ cpm: $\quad$ conjunctive participial marker \\ pm: $\quad$ past marker \\ y/n q mrk: $\quad$ yes/no question marker
}

\section{Bibliography

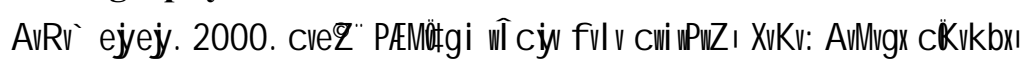

Ackerman, F. and G. Wbelhuth. 1998. A theory of predicates. California: CSLI Publications.

Baker, M. 1998. Incorporation: A Theory of Grammatical Function Changing. Chicago: University of Chicago Press.

Debarma, B. 2002. Anglo-Kokborok- Bengali Dictionary. $2^{\text {nd }}$ Edition. Agartala: Kokborok Tei Hukumu Mission (KOHM).

Chomsky, N. 1996. The Minimalist Program. Mass.: MIT Press.

Chomsky, N.1981. Lectures on Government and Binding: The Pisa Lectures. Holland: Foris Publications. Reprint. 7th Edition. Berlin and New York: Mouton de Gruyter, 1993.

Cole, P.1983. The Grammatical Role of the Causee in Universal Grammar. International Journal of American Linguistics, 49: 115-133

Comrie, B. 1999. $2^{\text {nd }}$ Edition. Language Universal and Linguistic Typology. Oxford: Blackwell Publications.

Comrie, B. 1996. The Syntax of Causative Construction: Cross-Linguistic similarities and Divergences. Syntax and Semantics, 6: 261-311

Comrie, B. 1976. Aspect: an introduction to the study of verbal aspect and related

problems.. Cambridge: Cambridge University Press

Comrie, B. 1975. Causatives and universal grammar. Transactions of the Philological Society, 1-32.

Davidson, D. 1967. Clausal Relations. The Journal of Philosophy, 64: 691703

Grierson, G. A. 2010. Linguistic Survey of India. Accessed on July 07, 2010, from http://www.britannica.com/ EBchecked/topic/ 342414/Linguistic-Survey-of-India

Grierson, G.A. 1927. Linguistic Survey of India, Vol.1 Part 1, Calcutta (Language of Sak, Lushei, Bowm, Pankhu, Mro, Arakanese, Tripura, Khyeang) 
Guha Thaurta, S.N. 1999. Tripura: India-the land and the people. New Delhi: National Book Trust.

Hale, K. and S.J. Keyser. 1993. On Argument Structure and the Lexical Expression of Syntactic relations. In K Hale and S.J. Keyser (ed.) The View from Building 20: Essays in Linguistics in Honour of Sylvain Bromberger. Cambridge, Mass.: MIT Press.

Jackendoff, R. 1990.Semantic Structure. Cambridge, Mass.: MIT Press.

Jacquesson, F. 2003. Kokborok, a short analysis. Hukumu, 10:109-122

Kunduchoudhury, K. 2006. Tripurara bhasa charcha: bangla o kokborok. Tripura: Akkhar Publications

Lakoff, G. 1987. Women, Fire and Dangerous Things. What Categories Reveal about the Mind. Chicago: Chicago University Press.

Matsumoto, Y.1996. Complex Predicates in Japanese: a Syntactic and Semantic Study of the Notion 'Word'. Tokyo and Stanford: Kuroshio and CSLI

Pai, P (Karapukar). 1976. Kokborok Gramamr. (CIIL Grammar Series;3). Mysore: Central Inst. of Indian Languages.

Shibatani, M. 1973. Where morphology and syntax clash: a case in Japanese aspectual verbs. Gengo Kenkyu, 64:65-96

Shibatani, M. 1996. The Grammar of Causative Constructions: A Conspectus. Syntax and Semantics, 6: 1-39 